\title{
Impact of Parameter Variations on the Steady State Behaviour of Grid Connected Renewable Energy Conversion Systems
}

\author{
Anly Abraham ${ }^{1 *}$ and D. Padma Subramanian ${ }^{2}$ \\ 'Department of EEE, Jerusalem College of Engineering, Chennai; anlya_e@yahoo.com \\ ${ }^{2}$ Faculty of Electrical and Electronics Engineering, AMET University, Kanathur, Chennai, Tamil Nadu, India; \\ subramanianpads@gmail.com
}

\begin{abstract}
This paper deals with impact of parameter variations such as wind speed, marine velocity and solar irradiation on the steady state behavior of grid connected renewable energy conversion systems (RECS) consisting of Wind Energy Conversion system (WECS), marine current energy conversion system and solar energy conversion system. A gird interfaced load flow program is developed in MATLAB platform and effectiveness of developed program is tested on a standard IEEE-9 bus system. The impact of varying wind speed, marine velocity and solar irradiation values on the steady state behavior of the grid-connected system is studied and the results are presented for a standard IEEE 9 bus system.
\end{abstract}

Keywords: Renewable Energy Systems; Steady State Analysis; Marine Current Energy Conversion System; Solar Energy Conversion System; Wind Energy Systems

\section{Introduction}

If environmental concerns keep growing, and restrictive guidelines constrain the use of the pollutant sources, wind, tidal and solar power can be considered as viable options for future electricity generation ${ }^{1}$. Besides being emissionfree, the energy coming from the wind, tidal and the sunrays is available at no cost. Due to massive increase in the prices of fossil fuels along with global warming issues, energy harvesting from renewable energy sources has received considerable interest. Wind is one of the most top growing renewable energy resources. Another promising form of renewable energy is tidal energy, which covers $70 \%$ of the earth's surface. The Earth receives an incredible supply of solar energy. The amount of solar radiation striking the earth over a three-day period is equivalent to the energy stored in all fossil energy sources ${ }^{2}$. Rural communities without hope to be connected to the public grid, lacking resources to keep up with the fuel prices or with unused diesel infrastructures, have found on hybrid systems the most suitable, environmentally friendly and cost competitive solution for power delivery. An integration of wind, tidal and sun light energy represents a new trend for large electric energy production.

Models for various wind turbine generating units have been developed $\mathrm{in}^{4}$ for steady state analysis. Impact of wind speed and terminal voltage variation on the behaviour of each type wind turbine generator unit is studied. Through load flow analysis on the radial distribution test system, impact of distributed wind generators on the voltage profile and losses have been discussed and resulta are presented.

Voltage Control and daming enhancement of a grid connected offshore wind farm and Marine Current farm is presented in $^{5}$ using a static synchronous compensator. Effecive damping for the controller is contributed by a damping controller designed to operate under different operating conditions. Time domai as well as

${ }^{*}$ Author for correspondence 
frequency domain approaches are adopted to prove the effectiveness of the controller under various disturbance conditions.

Variations on staedy state stability and output power on doubly fed induction generator by the variations in rotor excitation voltage is studied in $^{6}$. Magnitude and phase anle of the rotor excitatio voltage is derived based on the wind turbine mechanical speed characteristic and generator electro magnetic torque speed characteristic. Optimal rotor excitation voltage at which maximum power and minimum loss is found out and its impact on the stator resistance is studied.

Modeling and simulation of photovoltaic arrays and finding the parameters of the nonlinear I-V equation by adjusting the curve at open circuit, maximum power and short circuit conditions is presented in ${ }^{7}$. The best I-V equation for the PV model including the effect of series and parallel resistanceis found out. Modeling methods and simulation results are useful for power electronic designers.

This paper comprises of the following sections: Section 2 describes modelling of wind turbine, marine current turbine, DFIG and PV module for steady state analysis. In section 3 presents power flow analysis of grid connected renewable energy systems. Section 4 describes about test system used for steady state analysis. In section 5 , the results of power flow analysis of gird connected renewable energy system is discussed and illustrate the variation of voltage real power and reactive power with varying network parameters. Conclusion is presented in section 7 .

\section{Modeling for Steady State Analysis}

In this section, modelling of wind turbine, marine turbine, DFIG and for steady state analysis is presented.

\subsection{Wind Turbine Model}

The power obtained by the turbine is a function of wind speed. The simple model used commonly to represent the turbine is based on the power coefficient $\mathrm{C}_{\mathrm{p}}$ versus the tip speed ratio $\lambda^{3}$. The mechanical power extracted from the wind turbine is given by

$$
P_{\text {mech }}=\frac{1}{2} \rho A U_{w}^{3} C_{p}
$$

$\mathrm{C}_{\mathrm{p}}$ is a function of the blade pitch angle $\theta$ and the tip speed ratio $\lambda$ is defined as,

$$
\lambda=\frac{\omega R}{U_{w}}
$$

The variation of $C_{p}$ with the variation of wind speed $u_{w}$ and $\lambda$ is non-linear in nature $e^{4}$ The $\mathrm{C}_{\mathrm{p}}$ is generally represented as,

$$
\begin{gathered}
C_{p}(\lambda, \theta)=C_{1}\left(\frac{C_{2}}{\Lambda}-C_{3} \theta-C_{4} \theta^{x}-C_{5}\right) e^{\frac{-C_{6}}{\Lambda}} \\
\frac{1}{\Lambda}=\frac{1}{\lambda+0.08 \theta}-\frac{0.035}{\theta^{3}+1}
\end{gathered}
$$

where,

$\omega$ - Rotational speed of rotor ( in $\mathrm{rad} / \mathrm{s}$ ), R - Radius of swept area (in $\mathrm{m}$ )

$\theta$ - Pitch angle (in degree), $\mathrm{C}_{1}$ to $\mathrm{C}_{6}$ and $\mathrm{x}$ are constants

\subsection{Marine Current Turbine Model}

The marine current turbine (MCT) is assumed to be driven by tide speeds and the marine-current speed is determined by spring and neap tides. The marine-current speeds are given at hourly intervals starting at 6 hour before high waters and ending 6 hour after. Therefore, it is easy to derive a simple and practical model for marinecurrent speed under the known tide coefficients ${ }^{5}$. The marine current speed is given by

$$
V_{\mathrm{mr}}=V_{\mathrm{nt}}+\frac{\left(C_{\mathrm{mr}}-45\right)\left(V_{\mathrm{st}}-V_{\mathrm{nt}}\right)}{95-45}
$$

The mechanical power produced by an MCT is given by

$$
\mathrm{P}_{\mathrm{mr}}=\frac{1}{2} \rho_{\mathrm{mr}} \mathrm{A}_{\mathrm{mr}} \mathrm{V}_{\mathrm{mr}}^{3} \mathrm{C}_{\mathrm{pmr}}\left(\lambda_{\mathrm{mr}} \beta_{\mathrm{mr}}\right)
$$

The $C_{p m r}$ can be expressed as

$$
C_{p m r}=d_{1}\left[\frac{d_{1}}{\psi_{m r}}-d_{3} \beta_{m r}-d_{4}\left(\beta_{m r}\right)^{d_{5}}-d_{6}\right] e^{\left(-d_{7} / \psi_{m r}\right)}
$$

in which,

$$
\begin{gathered}
\frac{1}{\psi_{m r}}=\frac{1}{\lambda_{m r}+d_{2} \beta_{m r}}-\frac{d_{9}}{\left(\beta_{m r}\right)^{3}+1} \\
\lambda_{m r}=\frac{R_{B \omega r} \omega_{B m r}}{V_{m r}}
\end{gathered}
$$


Where,

Cmr - marine coefficient

Vst - spring marine-current speed (in $\mathrm{m} / \mathrm{sec}$ )

Vnt - neap marine-current speed (in $\mathrm{m} / \mathrm{sec}$ )

95 and 45 is the spring and neap tide medium coefficient respectively

$\rho_{m r}$ - water density $\left(1025 \mathrm{~kg} / \mathrm{m}^{3}\right)$

$A_{m r}$ - blade impact area (in $\left.\mathrm{m}^{2}\right)$

$V_{m r}$ - marine velocity (in $\mathrm{m} / \mathrm{sec}$ )

$\mathrm{d}_{1}$ to $\mathrm{d}_{9}$ are the constant coefficients of power coefficient of $C_{p m r}$

\subsection{Doubly Fed Induction Generator Model for Wind and Marine Energy Conversion System}

A doubly fed induction machine is a wound-rotor doubly fed electric machine. The steady state equivalent circuit of $\mathrm{DFIG}^{6}$ is shown in Figure 1.

The equations for stator and rotor real and reactive power are employed as given in ${ }^{6}$. The stator real power $\left(\mathrm{P}_{\mathrm{s}}\right)$ and reactive power $\left(\mathrm{Q}_{\mathrm{s}}\right)$ can be written as Equations (10) and (11) respectively, $P_{s} \quad R_{e} \overline{V_{s}} \overline{I_{s}}$

$$
\begin{aligned}
P_{s} & \frac{V_{s}^{2}}{A^{2} B^{2}}\left(\begin{array}{lll}
B_{r} & A s X_{r}
\end{array}\right) \\
& \frac{V_{s} V_{r}}{A^{2} \quad B^{2}}\left(\begin{array}{llll}
A X_{m} \cos & r & B X_{m} \sin & r
\end{array}\right)
\end{aligned}
$$

$$
\mathrm{Q}_{\mathrm{s}} \quad \operatorname{Im} \overline{\mathrm{V}_{\mathrm{s}}} \overline{\mathrm{I}_{\mathrm{s}}}
$$

Figure 1. Steady-state equivalent circuit of DFIG

$$
\begin{aligned}
Q_{s} \frac{V_{s}^{2}}{A^{2} B^{2}}\left(\begin{array}{llll}
A_{r} & B s X_{r}
\end{array}\right) \\
\frac{V_{s} V_{r}}{A^{2} B^{2}}\left(\begin{array}{lllll}
B X_{m} & \cos & r & A_{m} \sin & r
\end{array}\right)
\end{aligned}
$$

The rotor real power $\left(\mathrm{P}_{\mathrm{r}}\right)$ and reactive power $\left(\mathrm{Q}_{\mathrm{r}}\right)$ can be written as Eq (12) and (13) respectively, $P_{r} \quad R_{e} \quad \overline{V_{r}} \overline{I_{r}}$

$$
\begin{aligned}
& P_{r} \frac{V_{r}^{2}}{A^{2} \quad B^{2}}\left(B_{s} \quad A_{s}\right) \\
& \frac{s V_{s} V_{r}}{A^{2} \quad B^{2}}\left(A X_{m} \cos \quad r \quad B X_{m} \sin r\right) \\
& \mathrm{Q}_{\mathrm{r}} \quad \mathrm{Im} \overline{\mathrm{V}_{\mathrm{r}}} \overline{\mathrm{I}_{\mathrm{r}}} \mathrm{Q}_{\mathrm{r}} \\
& \mathrm{Q}_{\mathrm{r}} \frac{\mathrm{V}_{\mathrm{r}}^{2}}{\mathrm{~A}^{2} \mathrm{~B}^{2}}\left(\begin{array}{ll}
\mathrm{AR}_{\mathrm{s}} & \mathrm{BX} \mathrm{s}_{\mathrm{s}}
\end{array}\right) \\
& \frac{s V_{s} V_{r}}{A^{2} \quad B^{2}}\left(B X_{m} \cos r_{r} \quad A x_{m} \sin r\right)
\end{aligned}
$$

The expression for the electrical power can be obtained as

$$
\begin{gathered}
P_{e} \quad I_{r}^{2} R_{r} \frac{1 s}{s} \frac{1 s}{s} R_{e} \overline{V_{r}} \overline{I_{r}} \\
P_{e}=\frac{(s-1)}{A^{2}+B^{2}}(C+D+E)
\end{gathered}
$$

where,

$$
\begin{aligned}
& A=s R_{s} X_{r}+R_{r} X_{s}, \\
& B=R_{r} R_{s}+s\left(X_{m}^{2}-X_{r} X_{s}\right), \\
& C=s R_{r} X_{m}^{2} V_{s}^{2}-R_{s} X_{m}^{2} V_{r}^{2} \\
& D \quad\left(A \quad 2 R_{r} X_{s}\right) X_{m} V_{s} V_{r} \cos \quad r
\end{aligned}
$$

\section{PV Array Modeling}

\section{1) DC Part Model}

PV arrays are built up with combined series/parallel combinations of PV solar cells, which are usually represented by a simplified equivalent circuit model such as the one given in Figure 2 . 


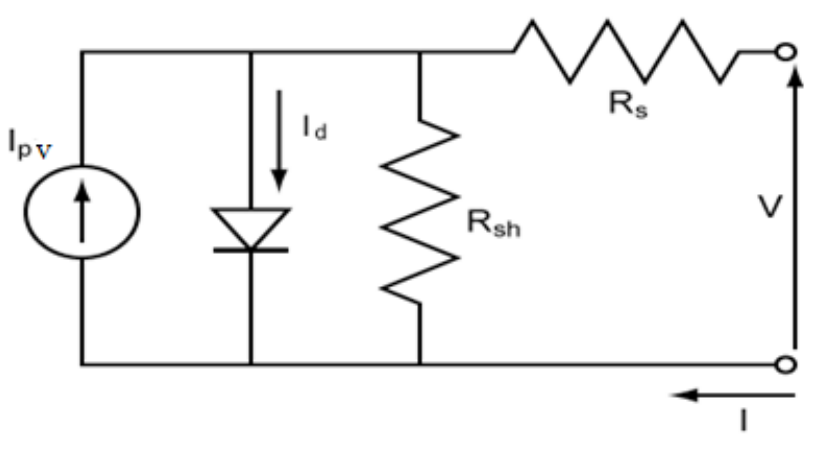

Figure 2. Equivalent circuit of PV cell

The voltage and current relationship of the simplified solar cell based on Kirchoff's current law can be expressed by the mathematical equation for the output current of single cell as

$$
I-I_{p v}-I_{0}\left[\exp \left(\frac{V+R_{s} I}{V_{t} a}\right)-1\right]-\frac{V+R_{s} I}{R_{s h}}
$$

where,

$I_{p v}$ - photovoltaic current of PV array

$I_{o}$ - leakage or reverse saturation current of PV array

$\mathrm{V}-\mathrm{PV}$ cell voltage

$V_{t}-\mathrm{N}_{\mathrm{s}} \mathrm{kT} / \mathrm{q}$ is the thermal voltage of array with $\mathrm{N}_{\mathrm{s}}$ cells connected in series

$\mathrm{R}_{\mathrm{s}}$ - equivalent series resistance of array (in ohms)

$\mathrm{R}_{\mathrm{sh}}$ - equivalent parallel resistance (in ohms)

$\mathrm{k}$ - Boltzmann constant $\left(1.3860503 \times 10^{-23} \mathrm{~J} / \mathrm{K}\right)$

$\mathrm{q}$ - electron charge $\left(1.60217646 \times 10^{-19} \mathrm{C}\right)$

a - ideality factor

The light generated current of the PV cell depends linearly on the solar irradiation and is also influenced by the temperature according to equation (16)

$$
I_{p v}=\frac{\left(I_{p v, n}+K_{1} \Delta T\right) G}{G_{n}}
$$

Here, $\quad T \quad T \quad T_{\mathrm{n}}$

The power of PV array can be calculated as

$$
P_{p v}=V_{p v}\left\{I_{p v}-I_{0}\left[\exp \left(\frac{q}{k T} \frac{V+R_{s} I}{a N_{s}}\right)\right]-1-\frac{V+R_{s} I}{R_{s h}}\right\}(17)
$$

\section{2) AC Part Model}

The schematic diagram of single stage PV inverter is shown in Figure 3. The average real power and average

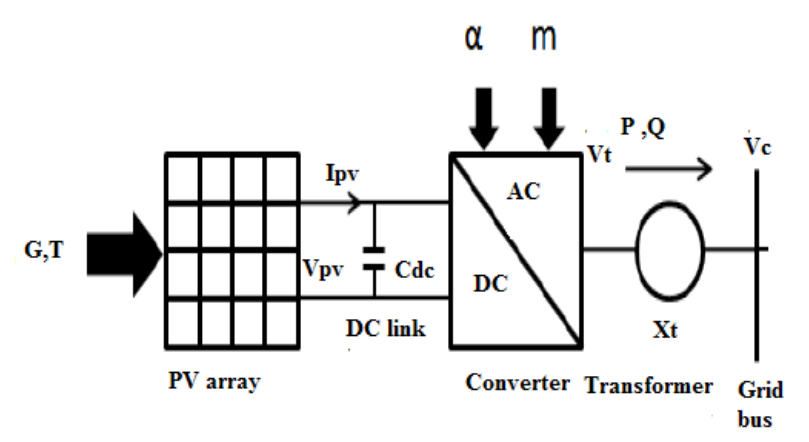

Figure 3. Schematic diagram of single stage PV inverter

reactive power output of the PV inverter to the grid ${ }^{7}$ can be expressed as Equations (18) and (19),

$$
\begin{gathered}
\mathrm{P} \frac{\mathrm{V}_{\mathrm{t}} \mathrm{V}_{\mathrm{c}}}{\mathrm{X}_{\mathrm{t}}} \sin \\
\mathrm{Q} \frac{\mathrm{V}_{\mathrm{t}}}{\mathrm{X}_{\mathrm{t}}\left(\mathrm{V}_{\mathrm{c}} \cos \mathrm{V}_{\mathrm{t}}\right)}
\end{gathered}
$$

where

$V_{t}$ - RMS value of terminal voltage

$V_{c}-$ RMS value of inverter output voltage

$X_{t}$ equivalent reactance of transformer phase angle difference of $\mathrm{V}_{c}$ and $\mathrm{V}_{t}$

$\mathrm{m}$ - modulation index

\section{Power Flow Analysis of Grid Connected Renewable Energy Conversion Systems}

The power flow study is to determine complete voltage angle and magnitude information for each bus in a power system for specified load and generator real power and voltage conditions. Once this information is known, real and reactive power flow on each branch as well as generator reactive power output can be analytically determined ${ }^{8}$.

The power-flow analysis with the renewable energy systems is complex, because, the power injected into the grid by renewable energy system like wind, marine and solar power system depends on the instantaneous wind speed, marine velocity and solar irradiation, which varies continuously. N-R power flow algorithm is reconstructed for the power flow formulation with renewable energy system is given below, 


$$
\begin{gathered}
{\left[\begin{array}{c}
\Delta P \\
\Delta Q \\
\Delta P_{W}
\end{array}\right]=\left[\begin{array}{lll}
\frac{d P}{d \theta} & \frac{d P}{d V} & \frac{d P}{d S_{W}} \\
\frac{d Q}{d \theta} & \frac{d Q}{d V} & \frac{d Q}{d S_{W}} \\
\frac{d P_{W}}{d \theta} & \frac{d P_{W}}{d V} & \frac{d P_{W}}{d S_{W}}
\end{array}\right]\left[\begin{array}{c}
\Delta \theta \\
\Delta V \\
\Delta S_{W}
\end{array}\right]} \\
{\left[\begin{array}{c}
\Delta P \\
\Delta Q \\
\Delta P_{T}
\end{array}\right]=\left[\begin{array}{lll}
\frac{d P}{d \theta} & \frac{d P}{d V} & \frac{d P}{d S_{M}} \\
\frac{d Q}{d \theta} & \frac{d Q}{d V} & \frac{d Q}{d S_{M}} \\
\frac{d P_{T}}{d \theta} & \frac{d P_{T}}{d V} & \frac{d P_{T}}{d S_{M}}
\end{array}\right]\left[\begin{array}{c}
\Delta \theta \\
\Delta V \\
\Delta S_{M}
\end{array}\right]} \\
{\left[\begin{array}{c}
\Delta P \\
\Delta Q \\
\Delta P_{S}
\end{array}\right]=\left[\begin{array}{lll}
\frac{d P}{d \theta} & \frac{d P}{d V} & \frac{d P}{d \alpha} \\
\frac{d Q}{d \theta} & \frac{d Q}{d V} & \frac{d Q}{d \alpha} \\
\frac{d P_{S}}{d \theta} & \frac{d P_{S}}{d V} & \frac{d P_{S}}{d \alpha}
\end{array}\right]\left[\begin{array}{l}
\Delta \theta \\
\Delta V \\
\Delta \alpha
\end{array}\right]}
\end{gathered}
$$

The Equations (20) to (22) represents the modified N-R matrix for grid interfaced wind energy system, marine energy system and PV generating system respectively.

where,

$P_{W}$ is power mismatch matrix of WT, given by $P_{W} \quad P_{\text {mech }} \quad P_{e}$ from Equations (1) and (14)

$P_{T}$ is power mismatch matrix of MCT, which is given by $\quad P_{T} \quad P_{m r} \quad P_{e}$ from Equations (6) and (14)

$P_{S}$ is power mismatch matrix of $\mathrm{PV}$ module, given by $P_{S} \quad P_{p v} \quad P$ from Equations (17) and (18)

\section{Description of Test System Used for Steady State Analysis}

In this paper, standard IEEE 9 bus system is considered for load flow analysis. Data for the system is provided in appendix.

The single diagram of standard IEEE- 9 bus system interfaced with wind energy system, marine energy system and PV generating system at $5^{\text {th }}$ bus is shown in Figures 4, 5 and 6 respectively.

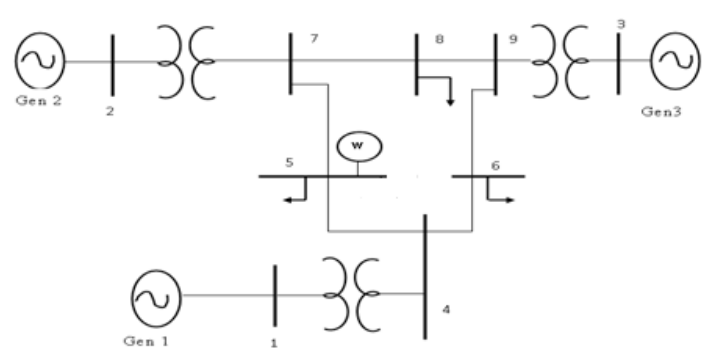

Figure 4. Grid interfaced wind energy conversion system

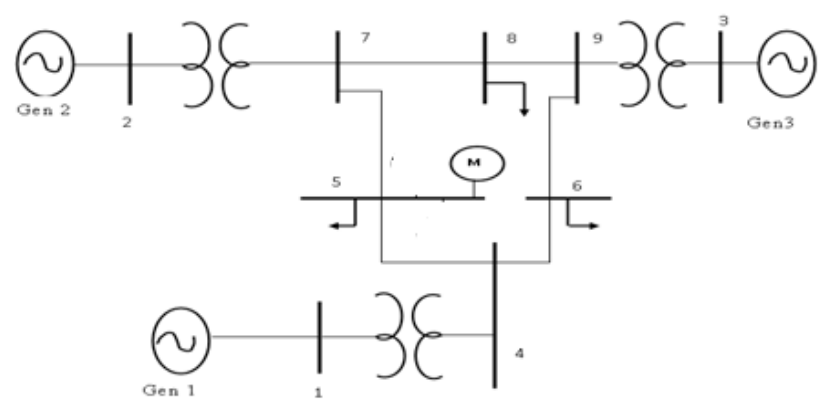

Figure 5. Grid interfaced marine energy conversion system

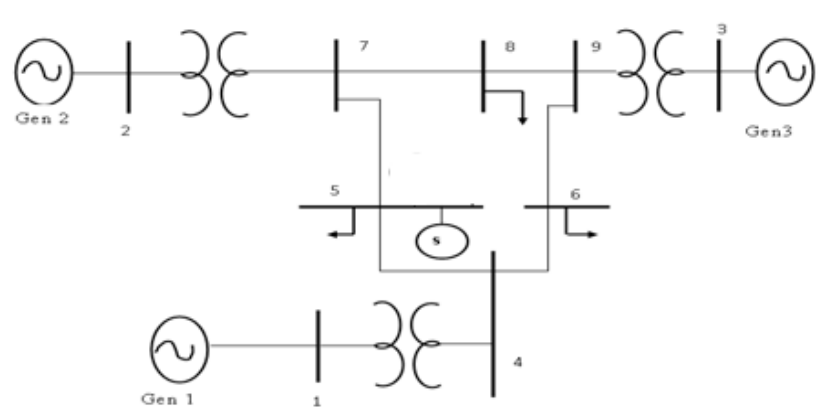

Figure 6. Grid interfaced solar energy conversion system

\section{Load Flow Analysis with Grid Connected Renewable Energy Power Systems}

The load flow analysis is carried out by interfacing renewable energy system such as WT, MCT and PV module into $5^{\text {th }}$ bus of IEEE 9 bus system. The load flow analysed is performed for each grind interfaced renewable energy system. 


\subsection{Load Flow Analysis with Wind Energy Conversion System}

The load flow routine is carried out for the system for wind speeds ranging from $5 \mathrm{~m} / \mathrm{sec}$ to $25 \mathrm{~m} / \mathrm{sec}$, and voltage and real power variations for different speed is observed. The results are plotted in Figures 7 and 8.

From the Figures 7 and 8 it can be observed that, voltage and real power increases gradually for low wind speeds and gradually decreases during high wind speed. The maximum power is generated at cut out speed of $17 \mathrm{~m} / \mathrm{s}$.

\subsection{Load Flow Analysis with Marine Energy Conversion System}

Load flow analysis is carried out with varying marine velocity ranging from $5 \mathrm{~m} / \mathrm{sec}$ to $25 \mathrm{~m} / \mathrm{sec}$. The variation of voltage and real power generation for marine velocity is plotted in Figures 9 and 10.

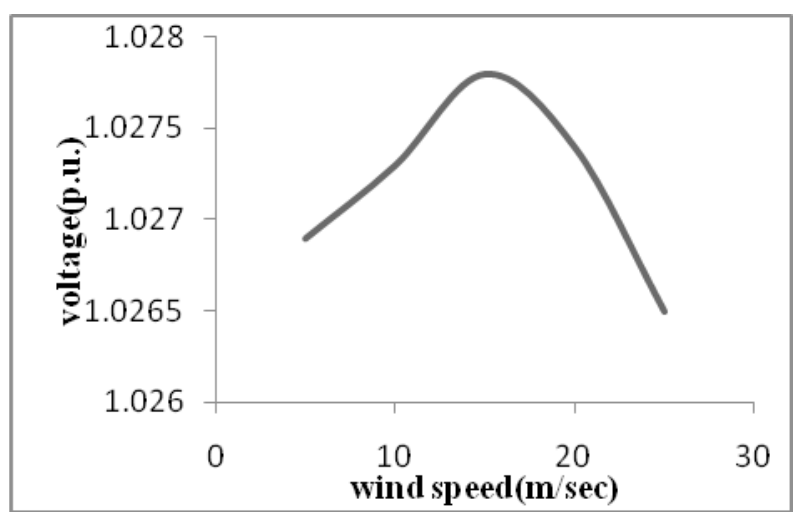

Figure 7. Voltage variation with varying wind speed

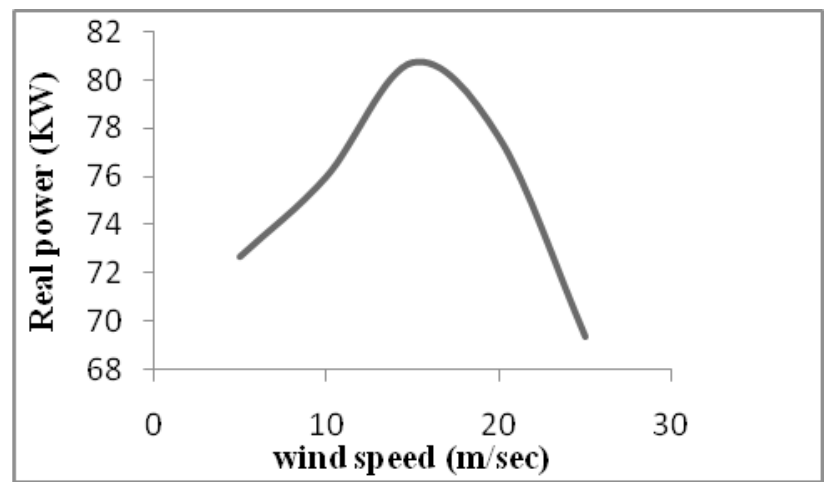

Figure 8. Real power variation with varying wind speed

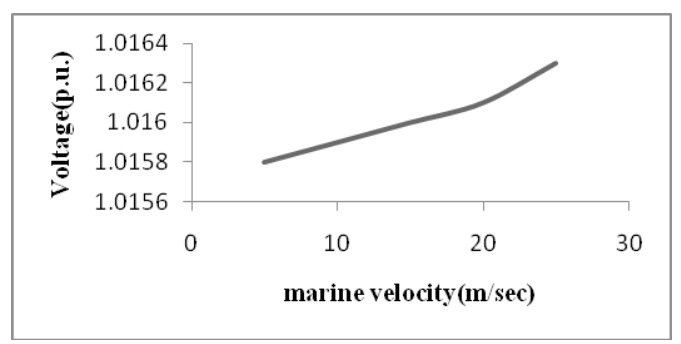

Figure 9. Voltage variation with varying marine velocity

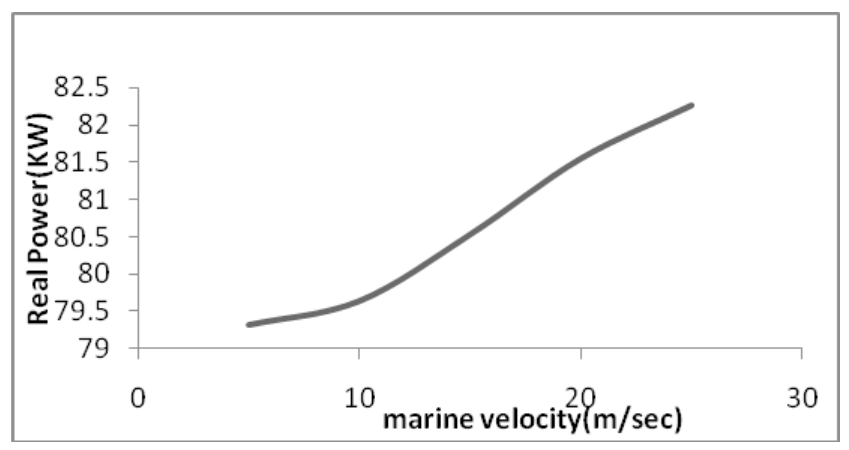

Figure 10. Real power variation with varying marine velocity

From Figure 9, it is clear that the voltage profile increases when marine velocity increases. The real power generation increases with marine velocity and it is clear form Figure 10. There is a need to find out the wind speed at which optimum real power and reactive power is achieved.

\subsection{Load Flow Analysis with Solar Energy Conversion System}

The power flow analysis is carried out by varying the irradiation value from $200 \mathrm{~W} / \mathrm{m}^{2}$ to $1000 \mathrm{~W} / \mathrm{m}^{2}$ and the result obtained are plotted in Figures 11 and 12.

Figure 11 shows the variation of voltage with irradiation, and it can be noted that the voltage increases with increase in the irradiation values. From Figure 12 it is observed that the real power generation gradually increases when the irradiation value varies from 200 to $1000 \mathrm{~W} / \mathrm{m}^{2}$. The reactive power also increases with irradiation value. 


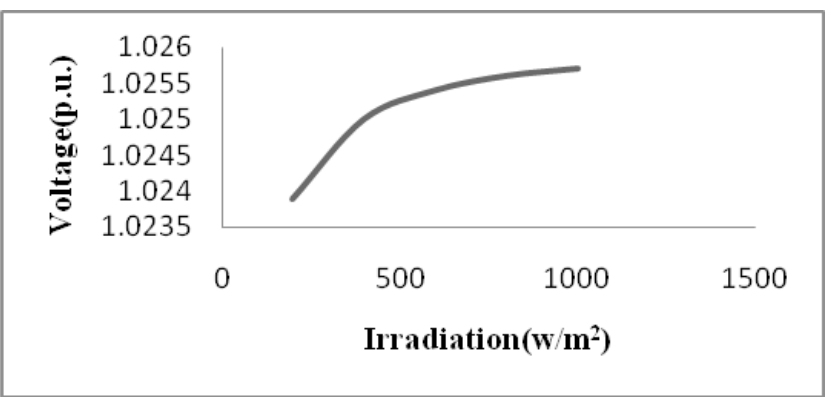

Figure 11. Voltage variation with varying irradiation

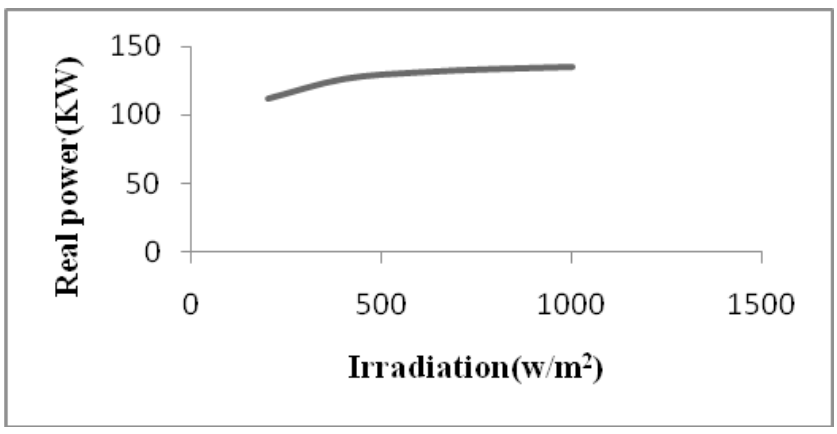

Figure 12. Real power variation with varying irradiation

\section{Conclusion}

In this paper, a load flow analysis is performed for grid interfaced renewable energy systems consisting of wind energy conversion system, marine energy conversion system and solar energy conversion system to study the impact of parameter variations such as wind speed, marine velocity and solar irradiation. A load flow program developed on MATLAB platform is tested on a standard IEEE-9 bus system. The load flow results show that the voltage and real power increases for an optimum value of wind speed, marine velocity and irradiation values, after which a gradual decrease is observed. Hence it is suggested that the performance of grid connected renewable energy system can be improved with the introduction of a controller for tracking maximum power.

\section{APPENDIX}

\subsection{IEEE-9 bus system data}

\section{1) Bus data}

\begin{tabular}{|c|c|c|c|c|c|c|c|c|}
\hline \multirow{2}{*}{$\begin{array}{l}\text { Bus } \\
\text { no }\end{array}$} & \multirow{2}{*}{$\begin{array}{l}\text { Bus } \\
\text { type }\end{array}$} & \multicolumn{2}{|c|}{$\begin{array}{c}\text { Generation } \\
\text { (p.u.) }\end{array}$} & \multicolumn{2}{|c|}{$\begin{array}{l}\text { Load } \\
\text { (p.u.) }\end{array}$} & \multicolumn{2}{|c|}{$\begin{array}{l}\text { DFIG } \\
\text { (p.u.) }\end{array}$} & \multirow{2}{*}{$\begin{array}{l}\text { Voltage } \\
\text { Magnitude } \\
\text { (p.u.) }\end{array}$} \\
\hline & & $P_{G}$ & $\mathrm{Q}_{\mathrm{G}}$ & $P_{L}$ & $\mathrm{QL}$ & $P_{\text {DFIG }}$ & $\mathrm{Q}_{\text {DFIG }}$ & \\
\hline 1 & Swing & - & - & - & - & - & - & 1.0400 \\
\hline 2 & PV & 1.63 & - & 0.00 & 0.0 & 0.0 & 0.0 & 1.0253 \\
\hline 3 & PV & 0.85 & - & 0.00 & 0.0 & 0.0 & 0.0 & 1.0253 \\
\hline 4 & PQ & 0.00 & 0.0 & 0.00 & 0.0 & 0.0 & 0.0 & - \\
\hline 5 & PQ & 0.00 & 0.0 & 1.25 & 0.0 & 0.2 & 0.1 & - \\
\hline 6 & PQ & 0.00 & 0.0 & 0.90 & 0.3 & 0.0 & 0.0 & - \\
\hline 7 & PQ & 0.00 & 0.0 & 0.00 & 0.0 & 0.0 & 0.0 & - \\
\hline 8 & PQ & 0.00 & 0.0 & 1.00 & 0.35 & 0.0 & 0.0 & - \\
\hline 9 & PQ & 0.00 & 0.0 & 0.00 & 0.0 & 0.0 & 0.0 & - \\
\hline
\end{tabular}

2) Line data

\begin{tabular}{lcccc}
\hline $\begin{array}{l}\text { From } \\
\text { Bus }\end{array}$ & $\begin{array}{l}\text { To } \\
\text { Bus }\end{array}$ & $\begin{array}{l}\text { Series } \\
\text { Resistance } \\
\text { (p.u.) }\end{array}$ & $\begin{array}{l}\text { Series } \\
\text { Reactance } \\
\text { (p.u.) }\end{array}$ & $\begin{array}{l}\text { Shunt } \\
\text { Susceptance } \\
\text { (p.u.) }\end{array}$ \\
\hline 1 & 4 & 0.0000 & 0.0576 & 0.0000 \\
4 & 6 & 0.0170 & 0.0920 & 0.1580 \\
6 & 9 & 0.0390 & 0.1700 & 0.0580 \\
9 & 3 & 0.0000 & 0.0586 & 0.0000 \\
9 & 8 & 0.0119 & 0.1008 & 0.2090 \\
8 & 7 & 0.0085 & 0.0720 & 0.1490 \\
7 & 2 & 0.0000 & 0.0625 & 0.0000 \\
\hline
\end{tabular}

\subsection{Wind energy Conversion System Data:}

Air density $=1.223 \mathrm{Kg} / \mathrm{m}^{3}$; Blade pitch angle $=30$ degree; Power coefficients $\mathrm{C}_{1}=0.5, \mathrm{C}_{2}=116, \mathrm{C}_{3}=0.4, \mathrm{C}_{5}=5, \mathrm{C}_{6}=21$ $\mathrm{P}=2 \mathrm{MW}$; Rs=0.00706 p.u.; Xls=0.171 p.u; $\mathrm{Xm}=2.9$ p.u; $\mathrm{Rr}=0.005 \mathrm{p} . \mathrm{u} ; \mathrm{Xlr}=0.156$ p.u . 


\subsection{Marine Energy Conversion System Data:}

Water density $=1025 \mathrm{Kg} / \mathrm{m}^{3}$ B Blade pitch angle=0 degree; Power coefficients $\mathrm{d} 1=0.18 ; \mathrm{d} 2=85 ; \mathrm{d} 3=0.38 ; \mathrm{d} 4=0.25$; $\mathrm{d} 5=0.5 ; \mathrm{d} 6=11 ; \mathrm{d} 7=10.9 ; \mathrm{d} 8=0.08 ; \mathrm{d} 9=0.01 ; \mathrm{P}=2.5 \mathrm{MW}$; $\mathrm{Rs}=0.01619$ p.u; $\mathrm{Xls}=0.1335$ p.u; $\mathrm{Xm}=3.99$ p.u; $\mathrm{Rr}=0.12 \mathrm{p} . \mathrm{u}$; $\mathrm{Xlr}=0.1121$ p.u.

\subsection{Solar Energy Conversion System Data}

Rs=0.221p.u; Rsh=0.415p.u; $\mathrm{a}=1.3 ; \mathrm{Isc}=8.21 \mathrm{~A}, \mathrm{~m}=1$; $\mathrm{Xl}=0.9$ p.u; $\mathrm{Gn}=1000 \mathrm{w} / \mathrm{m}^{2}, \mathrm{Tn}=25 \bigotimes \mathrm{C} ; \mathrm{Ipvn}=8.214 \mathrm{~A}$, $\mathrm{Ns}=54 ; \mathrm{K} 1=0.0032 \mathrm{~A} / \mathrm{K} ; \mathrm{V}=26.3 \mathrm{~V} ; \mathrm{k}=1.3806503 \times 10^{-23} \mathrm{~J} / \mathrm{K}$; $\mathrm{q}=1.60217646 \times 10^{-19}$.

\section{References}

1. Paiva and Carvalho, "An integrated hybrid power system based on renewable energy sources", $35^{\text {th }}$ Annual conference of IEEE on Industrial Electronics, 2009; 4548-4554.

2. Seif Eddine Ben Elghali, Mohamed El Hachemi Benbouzid, and Jean Frederic Charpentier, "Modeling and Control of a Marine Current Turbine Driven Doubly Fed Induction Generator", IET Renewable Power Generation, 2010; 4(1), 1-22.
3. S. N. Bhadra, D. Kastha, S. Banerjee, "Wind Electrical Systems", Oxford University Press, New Delhi, 2009.

4. Divya K.C. and Nagendra Rao P. S., "Models For Wind Turbine Generating Systems and Their Application in Load Flow Studies", Electric Power Systems Research, 2006; 844-856.

5. Li Wang and Chia-Tien Hsiung, "Dynamic stability improvement of an integrated grid-connected offshore wind farm and marine-current farm using a STATCOM", IEEE Transactions on power systems, 2011; 26(2), 690-698.

6. Chien-Hung Liu and Yuan-Yih Hsu, "Effect of rotor excitation voltage on steady state stability and maximum output power of a doubly fed induction generator", IEEE Transactions on Industrial Electronics, 2011; 58(4), 1096-1109.

7. Marcelo Gradella Villalva, Jonas Rafael Gazoli and Ernesto Ruppert Filho, "Comprehensive Approach to Modelling and Simulation of PhotovoltaicArrays", IEEE Transactions on power on power electronics, 2009.

8. Saadat H, "power System analysis", Tata Mc Graw Hill, New Delhi 1999, 2002 edition. 